\title{
Peningkatan Keterampilan Pembudidaya Ikan Melalui Pelatihan Pembuatan Pakan Herbal Untuk Kelompok Pembudidaya Ikan di Kelurahan Pahandut Seberang, Palangkaraya
}

\author{
Maryani $^{1}$, Ida Ratnasari ${ }^{2}$, Nursiah $^{3}$ \\ 1,2,3 Universitas Palangkaraya
}

\begin{abstract}
Article History ABSTRACT
Received 06.12.2018

Received in revised form IMPROVING THE SKILL OF FISH CULTIVATORS THROUGH HERBAL FEED SEBERANG VILLAGE, PALANGKARAYA. The fish farming business carried out by farmers is still traditional in nature, and until now it still relies on factory feed (pellets) as the main feed, besides that frequent disease outbreaks also follow it in fish cultivated in a cage due to frequent tides in the Kahayan River adding significant losses of farmers. Onion-Dayak as a typical Central Kalimantan medicinal plant contains phytochemical compounds, namely alkaloids, glycosides, flavonoids, phenolics, steroids, and tannins, which can be used as herbs. Therefore the author decided to carry out the Community Partnership Program in the form of training on making Dayak onion herbal feed to increase the knowledge and skills of fish farmers about the technique of making OnionDayak herbal feed for fish farming. The method used in achieving these objectives is through counseling and training activities. The results achieved after the training were that participants were able to understand and master the material about making Dayak onion herbal feed independently by utilizing raw materials around partner locations, so that fish feed needs during cultivation activities were fulfilled and did not depend on factory-made feed, and aquaculture protected from attacks diseases which ultimately can increase fish production.
\end{abstract}

KEYWORDS: Herbal Feed, Onion-Dayak, Pahandut-Seberang, Pellet, PKM.

DOI: $10.30653 / 002.201942 .147$

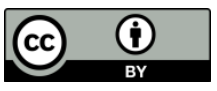

This is an open access article distributed under the terms of the Creative Commons Attribution 4.0 International License, which permits unrestricted use, distribution, and reproduction in any medium, provided the original work is properly cited. (c) 2019 Maryani, Ida Ratnasari, Nursiah.

\section{PENDAHULUAN}

Usaha budidaya ikan yang dilakukan oleh pembudidaya di Kelurahan Pahandut Seberang masih bersifat tradisional dan sampai saat ini masih mengandalkan pakan dari pabrik (pellet) sebagai pakan utama dari komoditi yang dibudidayakan yang dipelihara

${ }^{1}$ Corresponding author: Program Studi Budidaya Perairan Jurusan Perikanan Fakultas Pertanian Universitas Palangkaraya Jl. Yos Sudarso Kampus UPR Tunjung Nyaho, Indonesia; Email: maryani@ fish.upr.ac.id 
dalam jangka waktu 3-4 bulan permusim. Dengan intensitas pemberian pakan buatan (pellet) yang terus menerus sepanjang masa pemeliharaan dengan harga pakan buatan yang cukup mahal dan harga jual hasil panen yang cukup murah maka keuntungan pembudidaya sangat minim. Mahalnya biaya pembelian pakan menjadi salah satu penyebab rendahnya pendapatan pembudidaya. Selain membengkaknya kebutuhan pakan juga diikuti dengan sering terserangnya penyakit pada ikan yang dibudidayakan di karamba akibat sering terjadinya pasang surut air pada Sungai Kahayan menambah besar kerugian pembudidaya. Surutnya debit air Sungai Kahayan membuat khawatir para pembudidaya, karena mempengaruhi budidaya ikan keramba. Kondisi pasang surut bisa menyebabkan penyakit herpes pada ikan, sebab kejadian serupa sering dialami para petani sejak 2006 lalu. Bahkan hingga sekarang belum ada obatnya.

Kurangnya informasi yang diperoleh mitra tentang cara pembuatan pakan dan jenis bahan baku pakan menyebabkan pembudidaya ikan masih sangat tergantung pada pakan buatan, sehingga mitra atau pembudidaya ikan harus menyiapkan dana ekstra agar proses produksi dapat berjalan sesuai rencana dengan harapan hasil produksi dapat diperoleh secara maksimal. Pada budidaya ikan air tawar sendiri, informasi dan teknologi pakan alternatif yakni pakan yang dicampur dengan herbal telah berkembang dengan pesat (Gani, 2007; Sahami, 2003), salah satunya adalah pakan buatan herbal dari tanaman obat Bawang Dayak (Eleutherine palmifolia (L.) Merr). Tanaman obat ini merupakan tanaman khas Kalimantan Tengah, Secara empiris Bawang Dayak sudah dipergunakan masyarakat lokal sebagai obat berbagai jenis penyakit seperti kanker payudara, obat penurun darah tinggi (hipertensi), penyakit kencing manis (diabetes melitus), menurunkan kolesterol, obat bisul, kanker usus dan mencegah stroke penyakit. Dalam umbi Bawang Dayak terkandung senyawa fitokimia yakni alkaloid, glikosida, flavonoid, fenolik, steroid dan tannin.Sampai saat ini pengembangan dan pemanfaatan tanaman Bawang Dayak masih minim padahal manfaatnya sudah lama dirasakan masyarakat lokal Kalimantan Tengah.Tanaman ini memiliki adaptasi yang baik, dapat tumbuh dalam berbagai tipe iklim dan jenis tanah,umur tanaman pendek, sehingga tanaman ini dapat dengan mudah dikembangkan untuk skala industrimaupun industri rumahan/home industry (Galingging, 2009).

Kondisi mitra tersebut, perlu mendapatkan solusi yang tepat, salah satunya adalah upaya alih informasi dan penerapan teknologi pembuatan pakan herbal sebagai pendukung produksi ikan air tawar, selain mengurangi biaya produksi, juga dapat mengendalikan serangan penyakit yang biasanya menyerang ikan budidaya.

Berdasarkan berbagai permasalahan tersebut maka tujuan dari Pelaksanaan PKM ini adalah sebagai berikut:

1) Meningkatkan pengetahuan dan keterampilan mitra atau masyarakat pembudidaya ikan tentang teknik pembuatan pakan herbal untuk budidaya ikan dengan formulasi kandungan nutrisi yang sesuai dengan kebutuhan ikan budidaya.

2) Meningkatkan keterampilan mitra berkaitan metode penentuan komposisi dan formulasi bahan baku pakan ikan, sehingga dihasilkan pakan berkualitas dengan harga yang lebih terjangkau.

3) Meningkatkan pengetahuan mitra tentang cara pengendalian penyakit melalui pelatihan metode pemberian pakan herbal pada kegiatan budidaya ikan . 


\section{METODE PELAKSANAAN}

Berdasarkan permasalahan yang dihadapi kelompok mitra maka diperlukan penyuluhan dan pelatihan cara pembuatan pakan herbal bagi pembudidaya ikan budidaya di karamba dari tanaman obat khas Kalimantan Tengah, yakni Bawang Dayak (Eleutherine palmifolia (L.) Merr).

Metode dan langkah-langkah yang dilakukan adalah sebagai berikut: 1) Penyuluhan pembagian modul pelatihan cara pembuatan pakan herbal; 2) Pelatihan dengan mempraktekkan langsung cara pembuatan pakan herbal.

Peralatan yang digunakan dalam pelatihan adalah pisau, ember, penyaring, timbangan, nyiru, talenan, oven, blender, mesin penepung, mesin pengaduk, dan mesin pencetak dan bahan yang digunakan dalam pelatihan adalah umbi Bawang Dayak, tepung ikan, tepung jagung, tepung kedelai, dedak halus, ampas tahu, bungkil kelapa, polard dan bungkil kacang.

\section{Pelaksanaan Kegiatan}

Penyuluhan akan diberikan kepada kelompok pembudidaya ikan. Pada kegiatan ini akan dijelaskan pengetahuan tentang pembuatan pakan herbal pada budidaya ikan di karamba dengan menggunakan tanaman obat khas Kalimantan Tengah yakni Bawang Dayak, selanjutnya dilakukan tanya jawab dan diskusi.Pelatihan akan dilakukan dengan cara mempraktekan secara langsung cara pembuatan pakan herbal. Peserta terdiri dari 10 orang dengan nama kelompok Cemara Labat yang diketuai oleh Bapak Zain M. Lawen. Setelah pelatihan akan dilakukan pembinaan tiga bulan.

\section{Tahapan-tahapan Pelaksanaan}

Pembuatan simplisia Bawang Dayak melalui tahapan sebagai berikut (Galingging, 2009):

Penyortiran (segar), dilakukan setelah selesai panen dengan tujuan untuk memisahkan kotoran-kotoran atau bahan-bahan asing, bahan yang tua dengan yang muda atau bahan yang ukurannya lebih besar atau lebih kecil.

Pencucian, bertujuan menghilangkan kotoran-kotoran dan mengurangi mikrobamikroba yang melekat pada bahan. Pencucian harus segera dilakukan setelah panen karena dapat mempengaruhi mutu bahan. Perlu diperhatikan bahwa pencucian harus dilakukan dalam waktu yang sesingkat mung-kin untuk menghindari larut dan terbuangnya zat yang terkandung dalam bahan.

Penirisan/pengeringan. Alat pengering yang digunakan terbuat dari kawat yang berlubang untuk mempermudah sirkulasi udara, rimpang dibolak-balik secara periodik untuk memastikan keseragaman pengeringan serta mencegah fermentasi. Rak pengering harus bersih, tidak berkarat dan tidak bereaksi dengan rimpang yang dijemur serta ditempatkan pada tempat yang terlindung dari sinar matahari langsung. Pengeringan cukup dengan cara diangin-anginkan dan dilakukan sampai airnya tidak tiris lagi (4-6 hari).

Perajangan, biasanya hanya dilakukan pada bahan yang ukurannya agak besar dan tidak lunak seperti akar, rimpang, batang, buah dan lain-lain. Ukuran perajangan tergantung dari bahan yang digunakan dan berpengaruh terhadap kualitas simplisia yang dihasilkan. 
Pengeringan, merupakan suatu cara pengawetan atau pengolahan pada bahan dengan cara mengurangi kadar air, sehingga proses pembusukan dapat terhambat. Dengan demikian dapat dihasilkan simplisia terstandar, tidak mudah rusak dan tahan disimpan dalam waktu yang lama. Pengeringan bahan dapat dilakukan secara tradisional dengan menggunakan sinar matahari ataupun secara modern dengan menggunakan alat pengering seperti oven pada suhu $30-50^{\circ} \mathrm{C}$.

Penyortiran (kering), bertujuan untuk memisahkan benda-benda asing yang terdapat pada simplisia, misalnya akar-akar, pasir, kotoran unggas atau benda asing lainnya. Proses penyortiran merupakan tahap akhir dari pembuatan simplisia kering sebelum dilakukan pengemasan, penyimpanan atau pengolahan lebih lanjut.

Pengemasan, dapat dilakukan terhadap simplisia yang sudah dikeringkan. Jenis kemasan yang digunakan dapat berupa plastik, kertas maupun karung goni. Berikan label yang jelas pada tiap kemasan tersebut yang isinya menuliskan; nama bahan, bagian dari tanaman bahan yang digunakan, tanggal pengemasan, nomor/kode produksi, nama/alamat penghasil, berat bersih, metode penyimpanan.

Penyimpanan, dapat diakukan di ruang biasa (suhu kamar) ataupun di ruang ber AC. Ruang tempat penyimpanan harus bersih, udaranya cukup kering dan berventilasi.

\section{Cara Pembuatan Pakan Herbal}

Pembuatan pakan herbal Bawang Dayak dilakukan dengan menyiapkan bahanbahan yang diperlukan, yakni:

Tabel 1. Bahan-bahan Pembuatan Pakan Herbal Baawang Dayak

\begin{tabular}{|l|l|l|l|}
\hline No. & Bahan & Prosentase & Dalam 100 kg pakan \\
\hline 1. & Ampas tahu & $25 \%$ & $25 \mathrm{~kg}$ \\
\hline 2. & Tepung ikan & $5 \%$ & $5 \mathrm{~kg}$ \\
\hline 3. & Tepung jagung & $10 \%$ & $10 \mathrm{~kg}$ \\
\hline 4. & Bungkil kedelai & $10 \%$ & $10 \mathrm{~kg}$ \\
\hline 5. & Dedak halus & $15 \%$ & $15 \mathrm{~kg}$ \\
\hline 6. & Bungkil kelapa & $10 \%$ & $10 \mathrm{~kg}$ \\
\hline 7. & Polard & $15 \%$ & $15 \mathrm{~kg}$ \\
\hline 8. & Bungkil kacang & $10 \%$ & $10 \mathrm{~kg}$ \\
\hline 9. & Bawang Dayak & $15 \%$ & $15 \mathrm{~kg}$ \\
\hline
\end{tabular}

Cara pembuatan: Bahan-bahan ditimbang sesuai dengan komposisi pelet yang akan dibuat, kemudian bahan dituang ke mesin aduk atau mixer,perlu penambahan cairan sesuai keinginan.Setelah dimixer selama 10 menit dan adukan benar benar rata kemudian adukan dicetak dengan mesin pencetak pelet. Pelet yang keluar dari mesin ini langsung kering hanya perlu diangin - angin kan dengan kipas angin setelah itu pelet siap dipacking dan dipasarkan (Khairuman \& Khairul, 2002).

\section{Monitoring dan Evaluasi}

Keberhasilan kegiatan diukur dari monitoring dan evaluasi yang akan dilakukan secara berkala dengan mendatangi rumah warga untuk mengetahui sejauh mana pelatihan yang diberikan dapat diimplementasikan. 


\section{HASIL DAN PEMBAHASAN}

Hasil yang telah dicapai dari pelaksanaan kegiatan Program Kemitraan Masyarakat (PKM) adalah berjalannya seluruh kegiatan yang telah diprogramkan oleh tim pelaksana. Dengan menggunakan teknologi sederhana untuk pembuatan pelet pakan ikan yang dapat diproduksi sendiri. Kelebihan dari alternatif solusi ini adalah pembuatan pakan ikan secara mandiri dengan penambahan herbal tanaman khas masyarakat Dayak Kalimantan Tengah yakni Bawang Dayak (Eleutherine palmifolia (L.) Merr). Oleh karena itu, kegiatan Program Kemitraan Masyarakat dengan mitra Kelompok Cemara Labat Kelurahan Pahandut Seberang Kota Palangka Raya ini dilakukan dalam tiga tahapan yaitu: 1) penyuluhan pembuatan pakan herbal Bawang Dayak; 2) Pelatihan pembuatan pakan herbal Bawang Dayak; dan 3) Monitoring dan evaluasi.

\section{Penyuluhan Pembuatan Pakan Herbal Bawang Dayak}

Penyuluhan tentang permasalahan dalam budidaya ikan yang ada dimasyarakat dilakukan daerah Kelurahan Pahandut Seberang, Kota Palangka Raya. Kelompok mitra yang digandeng mempunyai anggota 10 orang dan semuanya hadir dalam kegiatan penyuluhan. Mitra yang bekerja sama merupakan petani ikan yang menggeluti usaha budidaya ikan air tawar. Sehingga dalam pelaksanaan kegiatan penyuluhan tim berupaya melakukan diskusi dengan masyarakat terhadap permasalahan yang dihadapi dan pemberian solusi atas masalah yang ditemukan oleh mitra. Hal yang didiskusikan dalam kegiatan tersebut adalah penggunaan pakan ikan secara mandiri sehingga biaya produksi dapat ditekan dengan tidak mengandalkan pakan buatan pabrik. Selain itu diskusi tentang penanggulangan permasalahan penyakit yang sering muncul pada kegiatan budidaya dengan pembuatan pakan yang ditambahkan herbal Bawang Dayak juga menjadi topik yang menarik bagi pembudidaya, karena hal ini merupakan hal yang baru bagi anggota kelompok pembudidaya tersebut. Gambar kegiatan diskusi ditampilkan dalam Gambar 1.

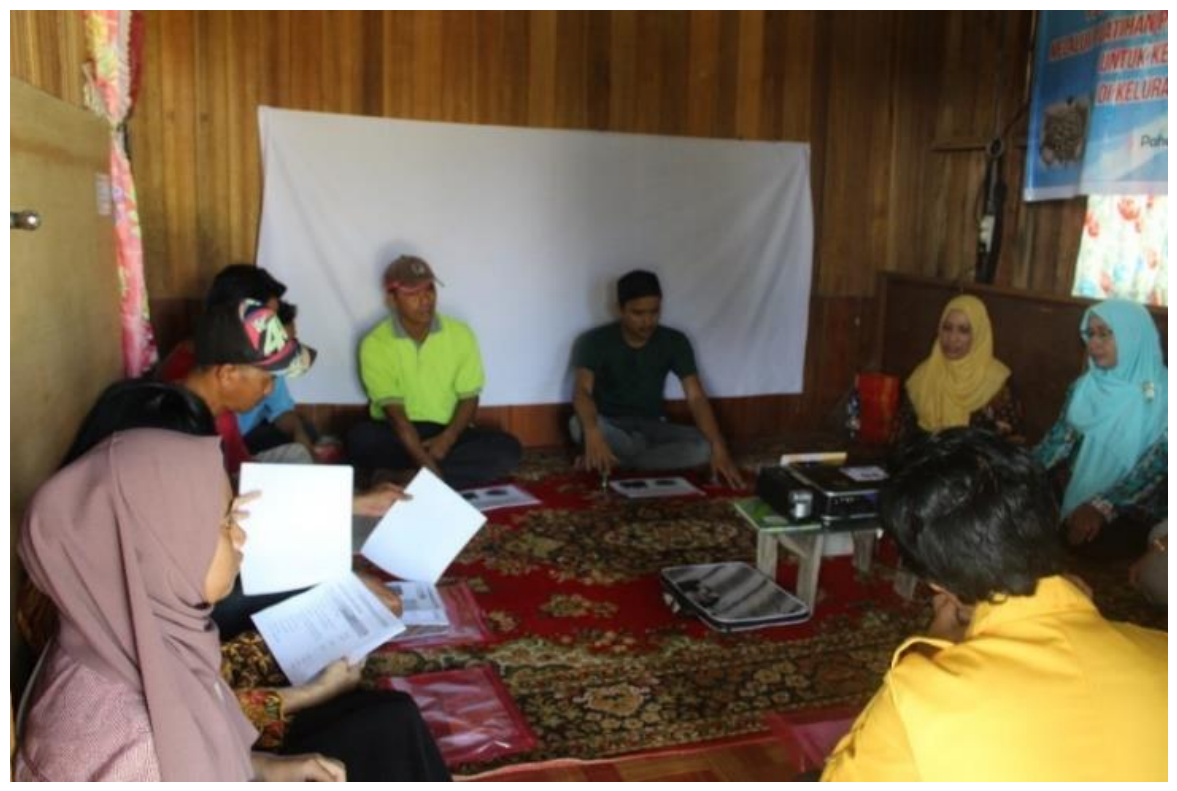

Gambar 1. Kegiatan Penyuluhan Pembuatan Pakan Herbal Bawang Dayak 
Selanjutnya, tim mengenalkan tumbuhan Bawang Dayak sebagai tanaman herbal yang akan ditambahkan pada pembuatan pakan ikan. Pemaparan dari bahan yang dikenalkan oleh tim sangat menarik perhatian pembudidaya yang hadir karena pemanfaatan Bawang Dayak yang mereka kenal sebagai herbal khas masyarakat Dayak Kalimantan Tengah selama ini hanya digunakan untuk manusia ternyata juga dapat dimanfaatkan dalam menanggulangi serangan penyakit yang muncul pada budidaya ikan.

Pada kegiatan penyuluhan tersebut dijelaskan bahwa pemakaian obat tradisional semakin berkembang pesat akhir-akhir ini. Perkembangan ini didukung oleh kecenderungan manusia melakukan pengobatan secara alam atau kembali ke alam (back to nature). Pengobatan secara tradisional dianggap lebih praktis karena sudah berlangsung turun temurun. Tanaman obat khas masyarakat Dayak Kalimantan Tengah sangat banyak ragamnya. Salah satu tanaman obat yang sudah dikembangkan khususnya di daerah Kalimantan Tengah adalah tanaman Bawang Dayak (Eleutherine palmifolia (L.) Merr). Ramuan Bawang Dayak sudah lama dimanfaatkan berbagai kalangan masyarakat Dayak sebagai obat alternatif karena mudah diperoleh dan harganya relatif murah dan tanaman ini gampang diperoleh masyarakat luas.

Bawang Dayak sudah banyak dibudidayakan di pekarangan sebagai TOGA (tanaman obat keluarga) dan ramuannya sudah banyak menyembuhkan penyakit . Lebih lanjut dijelaskan pula bahwa tanaman Bawang Dayak memiliki kandungan fitokimia antara lain alkaloid, glikosida, flavanoid, fenolik, steroid dan zat tannin yang merupakan sumber biofarmaka potensial untuk dikembangkan sebagai tanaman obat modern dalam kehidupan manusia.

Alkaloid merupakan bahan organik yang mengandung nitrogen sebagai bagian dari heterosiklik. Bahkan senyawa alkaloid, flavonoid, glikosida dan saponin memiliki aktivitas hipoglikemik atau penurun kadar glukosa darah yang sangat bermanfaat untuk pengobatan diabetes melitus, bahkan alkaloid yang ada dapat berfungsi sebagai anti mikroba. Sedangkan kandungan tanin yang ada dapat digunakan sebagai obat sakit perut. Penelitian tentang tanaman Bawang Dayak masih sangat kurang terutama dalam pengembangan sebagai bahan baku untuk pengembangan biofarmaka. Secara empiris diketahui tanaman ini dapat menyembuhkan penyakit kanker usus, kanker payudara, diabetes melitus, hiper-tensi, menurunkan kolesterol, obat bisul, stroke, sakit perut sesudah melahirkan. Kenyataan yang ada di masyarakat lokal merupakan bukti bahwa tanaman ini merupakan tanaman obat multifungsi yang sangat bermanfaat sehingga penelitian dan pengembangan lebih lanjut sangat diperlukan untuk kepentingan masyarakat.

\section{Pelatihan Pembuatan Pakan Herbal Bawang Dayak}

Praktik pembutan pakan ikan dengan penambahan herbal Bawang Dayak dilakukan di lokasi mitra yaitu mitra Cemara Labat, Kelurahan Pahandut Seberang Kec. Pahandut, Kota Palangka Raya. Komposisi pelet pakan ikan disesuaikan dengan hasil penyuluhan pada tahap pertama kegiatan. Pelatihan pembuatan pakan diawali dengan pembuatan simplisia Bawang Dayak. Tepung Bawang Dayak kemudian dicampurkan pada bahan pakan ikan yang akan dibuat. Komposisi yang telah diformulasi yaitu ampas tahu, tepung ikan, tepung jagung, bungkil kedelai, dedak halus, bungkil kelapa, vitamin, bungkil kacang dan Bawang Dayak diaduk sampai homogen. Ditambah kanji yang sebelumnya 
ditambah air panas untuk perekat dalam pembuatan pelet. Bahan-bahan dicampur sampai kalis. Setelah adonan kalis, adonan dicetak dengan mesin pencetak pelet sederhana dan ditampung dalam loyang. Pelet dikeringkan di bawah sinar matahari sampai kering. Proses produksi yang sangat sederhana menjadikan metode ini menjadi alternatif dalam menangani permasalahan tingginya biaya pakan dalam budidaya ikan. Pelaksanaan kegiatan pembuatan pakan ikan dengan mitra ditampilkan dalam Gambar 2

Untuk mengukur tingkat keberhasilan Program Kemitraan Masyarakat (PKM) ini dilakukan evaluasi terhadap keseluruhan proses. Hasil evaluasi menunjukkan bahwa kegiatan ini memenuhi kriteria keberhasilan yang telah ditetapkan. Hal ini dapat dilihat dari kriteria keberhasilan, yaitu:

1) $90 \%$ tingkat wawasan, pengetahuan dan pemahaman tentang pembuatan pakan herbal Bawang Dayak untuk meningkatkan produksi ikan dapat diserap (dikuasai) oleh mitra masyarakat. Hasil yang di capai telah memenuhi kriteria keberhasilan yang telah ditetapkan sebelumnya.

2) Setelah penyuluhan, tim pengabdi mendemontrasikan teknik meramu pakan herbal Bawang Dayak. Selanjutnya peserta diberi kesempatan untukmempraktekan sendiri tentang teknik meramu pakan herbal Bawang Dayak. Berdasarkan pengamatan terhadap kemampuan/ketrampilan peserta pelatihan dalam menerapkan teknik meramu pakan herbal Bawang Dayak terlihat sekitar 90\% dari seluruh peserta pelatihan mampu melakukan pembuatan pakan herbal Bawang Dayak

\section{Monitoring dan Evaluasi}

Setelah kegiatan penyuluhan dan praktek pembuatan pakan herbal Bawang Dayak dilakukan, dua bulan kemudian dilakukan monitoring dan evaluasi terhadap program yang telah dijalankan. Hasil evaluasi yang dilakukan menunjukkan kegiatan ini berjalan dengan lancar. Transfer ilmu dan teknologi yang dilakukan sebelumnya diserap dengan baik oleh mitra. Saat ini, mitra sudah mengaplikasikan hasil kegiatan dengan memberikan pakan herbal Bawang Dayak untuk ikan budidaya mereka.

Pada sisi lain, mitra juga sedang melakukan formulasi terhadap bahan-bahan yang digunakan dalam pembuatan pakan sesuai dengan kebutuhan nutrisi ikan yang mereka kelola. Untuk mengukur nilai gizi seperti protein dan karbohidrat, tim membantu melakukan analisa di laboratorium. Selanjutnya, hasil yang diperoleh di laboratorium disampaikan kepada mitra untuk dikembangkan lebih lanjut. Mitra dalam kegiatan ini sangat antusias untuk mengembangkan hasil kegiatan ini. Mitra berupaya untuk melakukan produksi untuk memenuhi kebutuhan pakan ikan anggotanya.

Selanjutnya, harapan mitra yang patut diapresiasi adalah keinginan mitra untuk melakukan produksi pelet pakan herbal Bawang Dayak untuk dijual di masyarakat sekitar dengan mengacu pada pengalaman formulasi yang dilakukan di lapangan setiap harinya. Tentunya, tim akan terus membantu mitra dalam menyediakan layanan analisis kandungan gizi jika diperlukan. Upaya tersebut tentunya merupakan kerjasama yang sangat baik antara akademisi dan praktisi. 


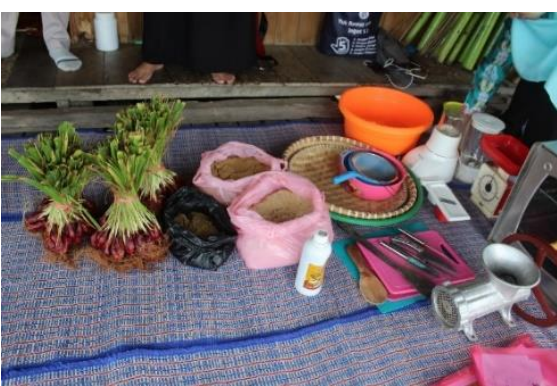

(1)

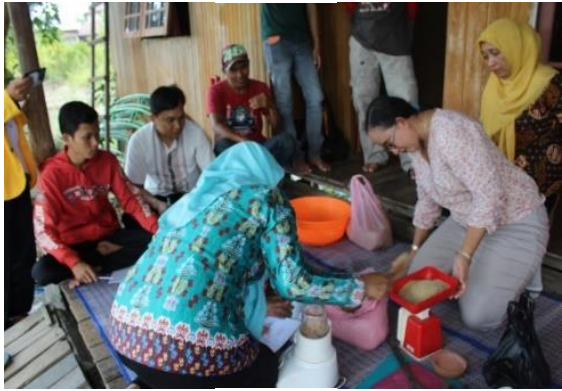

(3)

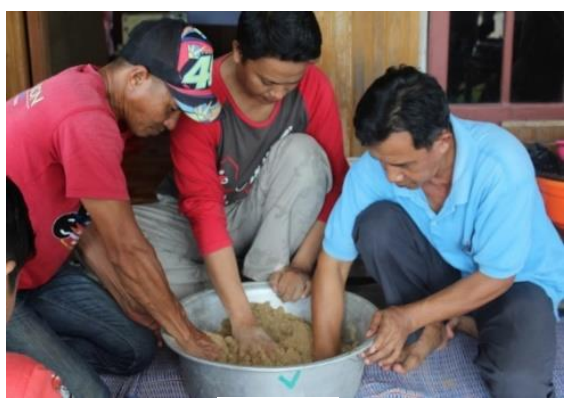

(5)

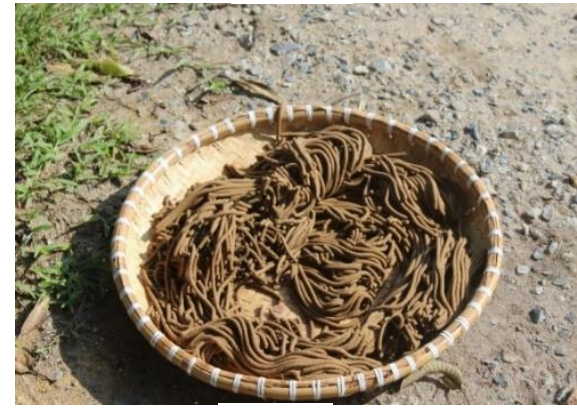

(7)

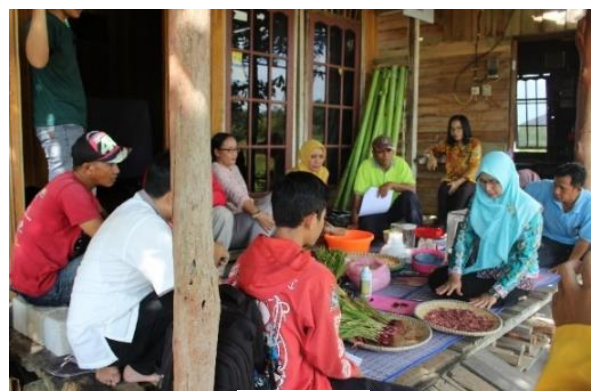

(2)

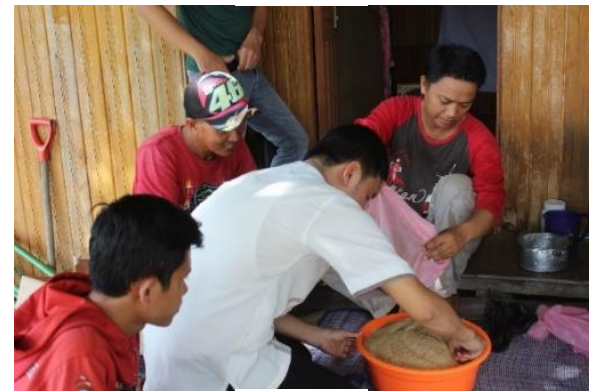

(4)

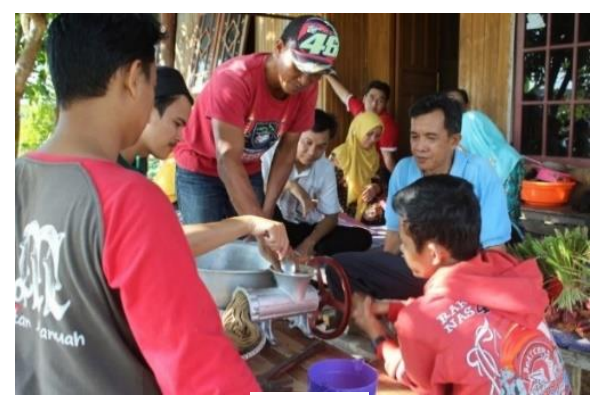

(6)
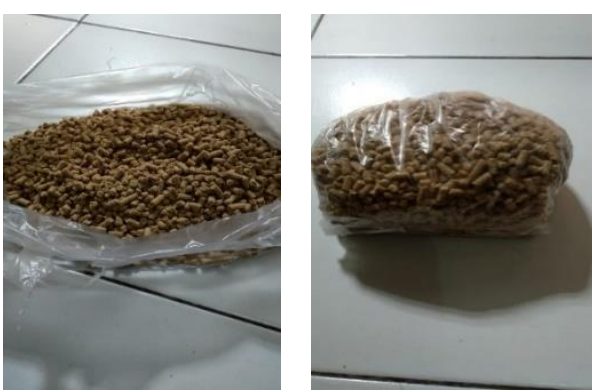

(8)

Keterangan: (1) mempersiapkan alat dan bahan; (2) mengolah tepung Bawang Dayak; (3) penimbangan bahan baku pakan; (4) mencampur semua bahan hingga rata; (5) pengadukan adonan (6) mencetak pelet;(7) hasil cetakan pelet dikeringkan; (8) packing hasil.

Gambar 2. Prosedur Pembuatan Pakan Herbal Bawang Dayak 
Melalui program ini, tim PKM telah membantu memberikan pelatihan keterampilan pembuatan pakan herbal Bawang Dayak. Pelatihan ini merupakan inovasi baru sebagai wujud kepedulian dan pengabdian pada kelompok pembudidaya ikan di Kelurahan Pahandut Seberang, dengan harapan nantinya para pembudidaya ikan yang telah mengikuti pelatihan juga dapat membagi pengetahuan yang telah mereka peroleh kepada kelompok pembudidaya ikan lainnya, sehingga kedepannya dapat terwujud mitra binaan yang dapat memproduksi pakan ikan herbal Bawang Dayak secara mandiri dengan mengoptimalkan potensi bahan baku pakan yang ada di wilayah mitra, dengan memanfaatkan tanaman obat khas Kalimantan Tengah yakni Tanaman Obat Bawang Dayak, sehingga kebutuhan pakan ikan selama kegiatan budidaya terpenuhi dan tidak tergantung pakan buatan pabrikan, serta ikan budidaya terhindar dari serangan penyakit.

\section{SIMPULAN}

Setelah melakukan kegiatan PKM Pembuatan Pakan Herbal Bawang Dayak bagi kelompok pembudidaya ikan di Kelurahan Pahandut Seberang, maka dapat disimpulkan bahwa seluruh kegiatan Program Kemitraan Masyarakat (PKM) dapat dilaksanakan dan terealisasi sesuai dengan perencanaan. Indikator capaian yang ditetapkan telah berhasil dicapai diantaranya adalah:

Hasil evaluasi tingkat pemahaman penguasaan materi PKM diperoleh bahwa 90\% masyarakat peserta kegiatan PKM menguasai dan memahami tentang: tumbuhan khas Kalimantan Tengah yang dapat dijadikan sebagai obat dalam penanggulangan serangan penyakit ikan budidaya, pemilihan bahan pakan, teknik penyusunan formulasi bahan pakan, teknik pencampuran bahan, produksi pakan pellet, pengemasan pakan sampai dengan teknik pemberian pakan.

Peserta dapat membuat pakan herbal Bawang Dayak secara mandiri dengan memanfaatkan bahan baku yang di sekitar lokasi mitra dengan memanfaatkan tanaman obat khas Kalimantan Tengah yakni Tanaman Obat Bawang Dayak sehingga kebutuhan pakan ikan selama kegiatan budidaya terpenuhi dan tidak tergantung pakan buatan pabrikan, serta ikan budidaya terhindar dari serangan penyakit.yang pada akhirnya mampu meningkatkan produksi ikan.

Kegiatan monitoring dan evaluasi berhasi dilaksanakan yang ditunjukkan dengan mitra terus menggunakan hasil kegiatan setelah kegiatan berjalan selama 3 bulan.

\section{REFERENSI}

Galingging, R. Y. (2009). Bawang dayak (Eleutherine palmifolia) sebagai tanaman obat multifungsi. Warta Penelitian dan Pengembangan, 15(3), 2-4.

Gani, N. (2007). Pengaruh campuran pakan alternatif terhadap pertumbuhan ikan nila. (Skripsi tidak dipublikasikan). Gorontalo: Universitas Negeri Gorontalo.

Khairuman, A., \& Khairul, A. (2002). Membuat pakan ikan konsumsi. Jakarta: Agromedia Pustaka.

Prasetio, B. (23). 23 peluang usaha top bidang agribisnis. Yogyakarta: Penerbit Andi. 
Jurnal Pengabdian Pada Masyarakat 2019, 4(2), 153-162

Sahami, S. (2003). Pengaruh pemotongan sirip ekor terhadap pertumbuhan ikan nila hitam (oreochromis niloticus, l) di jaring apung. (Skripsi). Gorontalo: IKIP Negeri Gorontalo.

Sahwan, M. F. (2002). Pakan ikan dan udang; Formulasi: pembuatan: Analisis ekonomi. Jakarta: Penebar Swadaya. 